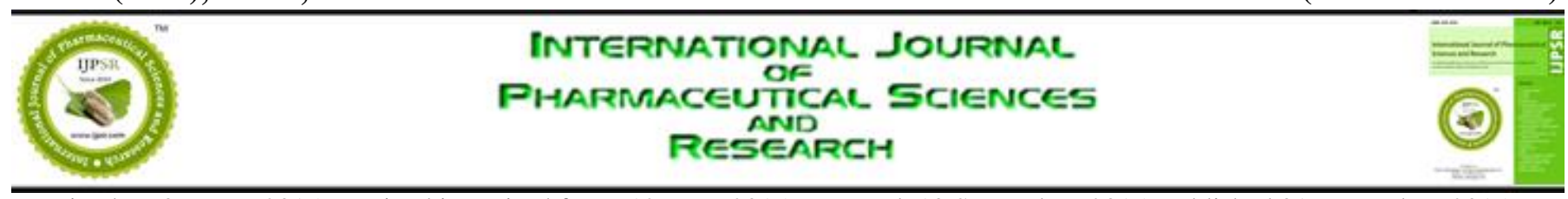

Received on 06 May, 2015; received in revised form, 12 June, 2015; accepted, 10 September, 2015; published 01 November, 2015

\title{
DEVELOPMENT AND VALIDATION OF ANALYTICAL METHOD FOR SIMULTANEOUS DETERMINATION OF MINOXIDIL AND FINASTERIDE IN PHARMACEUTICAL DOSAGE FORM BY RP-HPLC METHOD
}

Nivedita Patel and Dhananjay Meshram*

Department of Quality Assurance, Pioneer Pharmacy Degree College, Pioneer Medical Campus near Ajwa Cross Road NH-8 Ajwa -Nimeta Road, At \& Post- Sayajipura, Vadodara-390019, Gujarat, India.

Keywords:

Finasteride, Minoxidil, RP-HPLC, Validation

Correspondence to Author:

Dr. Dhananjay Meshram

Principal

Pioneer Pharmacy Degree College

Pioneer Medical Campus near Ajwa

Cross Road, NH-8 Ajwa-Nimeta

Road, At \& Post- Sayajipura,

Vadodara-390019, Gujarat, India.

E-mail: dbmeshram@yahoo.com
ABSTRACT: A simple, precise, rapid, accurate RP-HPLC method has been developed and validated for the simultaneous determination of Minoxidil and Finasteride in pharmaceutical dosage form. The chromatographic separation was achieved on ODS $\mathrm{C}_{18}$ column $(25 \mathrm{~cm} \times 4.6 \mathrm{~mm}, 5 \mu$ particle size $)$ using a mobile phase comprising methanol: water along with $0.5 \%$ triethyl amine (TEA), pH 6.38 adjusted with ortho phosphoric acid (OPA) in a ratio of 70:30 v/v. The flow rate was $1 \mathrm{ml} / \mathrm{min}$ and eluents were detected by UV detector at $210 \mathrm{~nm}$. Retention times were found to be $4.661 \mathrm{~min}$ and $10.005 \mathrm{~min}$ of Finasteride and Minoxidil respectively. The calibration curve was linear over the range of $12-24 \mu \mathrm{g} / \mathrm{ml}$ of Minoxidil and $0.4-$ $0.8 \mu \mathrm{g} / \mathrm{ml}$ of Finasteride. The results of all the validation parameters were well within their acceptance values. The developed method was successfully applied for determination of the two drugs from its pharmaceutical formulation. The excipients in the formulation do not pose any hindrance in determination of the two drugs. The proposed method is suitable for routine quality control analysis.
INTRODUCTION: Chemically, Minoxidil (MINO) is 2, 4-diamino-6-piperidinopyrimidine 3oxidemainly used for the hair growth stimulator ${ }^{1}$. MINO, when applied topically to the scalp may stimulate hair growth to a limited extent followed by opening of $\mathrm{K}^{+}$channels and enhanced microcirculation around hair follicles ${ }^{2}$. Chemically, Finasteride (FINA) is $17 \beta$ (N-tertbutylcarbamoyl)-4-aza - $5 \alpha$-androst -1 - en - 3onemainly used in the treatment of androgenic alopecia. FINA, blocks the peripheral conversion of testosterone to dihydrotestosterone (DHT), resulting in to the decrease scalp DHT concentration to the levels found in hairy scalp, reduce serum DHT, increase hair regrowth, and slow hair loss ${ }^{2}$.

\begin{tabular}{|l|c|}
\hline QUICK RESPONSE CODE & DOI: \\
\hline DOI link: http://dx.doi.org/10.13040/IJPSR.0975-8232.6(11).4882-85 \\
\hline
\end{tabular}

The literature survey revealed methods for estimation of MINO by spectrophotometry 3 , RP-HPLC " stability indicating HPLC 5, electrochemical determination ${ }^{6}$ and voltammetric method ${ }^{7}$ and methods for estimation of FINA by spectrophotometry ${ }^{8}$, RP-HPLC ${ }^{9-10}$ and stability indicating HPLC method ${ }^{11}$. Recently one RPHPLC method ${ }^{12}$ has been published for simultaneous determination of both the drugs in their pharmaceutical formulation.

\section{MATERIALS AND METHODS:}

Preparation of standard stock solution:

An accurately weighed $300 \mathrm{mg}$ of MINO and 10 $\mathrm{mg}$ of FINA were transferred to $100 \mathrm{ml}$ volumetric flasks, dissolved in a HPLC grade methanol and diluted up to $100 \mathrm{ml}$ with HPLC grade methanol to give solution of concentration of a $3000 \mu \mathrm{g} / \mathrm{ml}$ of MINO and $100 \mu \mathrm{g} / \mathrm{ml}$ of FINA.

Preparation of working standard solution: 300 $\mu \mathrm{g} / \mathrm{ml}$ of $\mathrm{MINO}$ and $10 \mu \mathrm{g} / \mathrm{ml}$ of FINA solution 
were prepared by diluting $10 \mathrm{ml}$ of MINO and FINA stock solution with HPLC grade methanol in $100 \mathrm{ml}$ volumetric flasks.

\section{Preparation of sample solution:}

$1 \mathrm{ml}$ of formulation equivalent to $30 \mathrm{mg}$ of MINO and $1 \mathrm{mg}$ of FINA was taken in $100 \mathrm{ml}$ volumetric flask, $60 \mathrm{ml}$ of HPLC grade methanol was added, sonicated for $30-35 \mathrm{~min}$ and diluted to $100 \mathrm{ml}$ with HPLC grade methanol. This solution was filtered through Whatmann filter paper No.41 $(300 \mu \mathrm{g} / \mathrm{ml}$ of MINO and $10 \mu \mathrm{g} / \mathrm{ml}$ of FINA). From this solution $0.5 \mathrm{ml}$ was transferred to $10 \mathrm{ml}$ volumetric flask and volume made up with methanol to achieve a concentration of $15 \mu \mathrm{g} / \mathrm{ml}$ of MINO and $0.5 \mu \mathrm{g} / \mathrm{ml}$ of FINA.

\section{Chromatographic conditions}

Chromatographic separation was performed on $\mathrm{C}_{18}$ (Shim pack xR ODS II $25 \mathrm{~cm} \times 4.6 \mathrm{~mm}, 5 \mu$ particle size) column. The composition of mobile phase was methanol: water along with $0.5 \%$ TEA, $\mathrm{pH} 6.38$ adjusted with OPA (70:30 v/v). The mobile phase was delivered at a flow rate of 1 $\mathrm{ml} / \mathrm{min}$. Analysis was performed at ambient temperature. Injection volume was $20 \mu \mathrm{l}$ and detection was carried out at $210 \mathrm{~nm}$.

\section{RESULTS:}

\section{Optimization of chromatographic conditions:}

Chromatographic conditions were optimized by changing the mobile phase composition. Different experiments were performed to optimize the mobile phase and results are given in Table 1. Optimized mobile phase consists of a methanol: water along with $0.5 \%$ TEA, $\mathrm{pH} 6.38$ adjusted with OPA $(70: 30 \mathrm{v} / \mathrm{v})$ with flow rate of $1 \mathrm{ml} / \mathrm{min}$. FINA and MINO were eluted at 4.661 and 10.005 minutes respectively with a run time of 13 minutes. Fig.1 depicts typical chromatogram for simultaneous determination of MINO and FINA.

TABLE 1: OPTIMIZATION OF MOBILE PHASE

\begin{tabular}{|c|c|c|c|c|c|c|}
\hline \multirow[t]{2}{*}{ Trial } & \multirow[t]{2}{*}{ Mobile phase } & \multirow{2}{*}{$\begin{array}{c}\text { Flow rate } \\
(\mathrm{ml} / \mathrm{min})\end{array}$} & \multirow[t]{2}{*}{ Ratio } & \multicolumn{2}{|c|}{ Retention time (min) } & \multirow[t]{2}{*}{ Remark } \\
\hline & & & & MINO & FINA & \\
\hline 1. & ACN: water & 1 & $70: 30$ & 7.717 & 4.582 & $\begin{array}{l}\text { Peak was observed but height of } \\
\text { Minoxidil peak was more as } \\
\text { compare to Finasteride peak. }\end{array}$ \\
\hline 2. & ACN: water & 1 & $36: 46$ & 15.457 & 4.652 & $\begin{array}{l}\text { Both broad peaks were observed } \\
\text { with tailing. }\end{array}$ \\
\hline 3. & $\begin{array}{l}\text { ACN: water with } 0.1 \% \\
\text { TEA, pH } 6.92 \text { adjusted } \\
\text { with OPA }\end{array}$ & 1 & $60: 40$ & 8.138 & 4.038 & $\begin{array}{l}\text { Peak was observed with tailing, } \\
\text { splitting and less theoretical } \\
\text { plates. }\end{array}$ \\
\hline 4. & Methanol: water & 1 & $70: 30$ & 10.225 & 4.680 & Peaks were observed with tailing. \\
\hline 5. & $\begin{array}{l}\text { Methanol: water with } \\
0.5 \% \text { TEA, pH } 6.38 \\
\text { adjusted with OPA }\end{array}$ & 1 & $70: 30$ & 10.005 & 4.661 & Sharp peaks with good resolution. \\
\hline
\end{tabular}

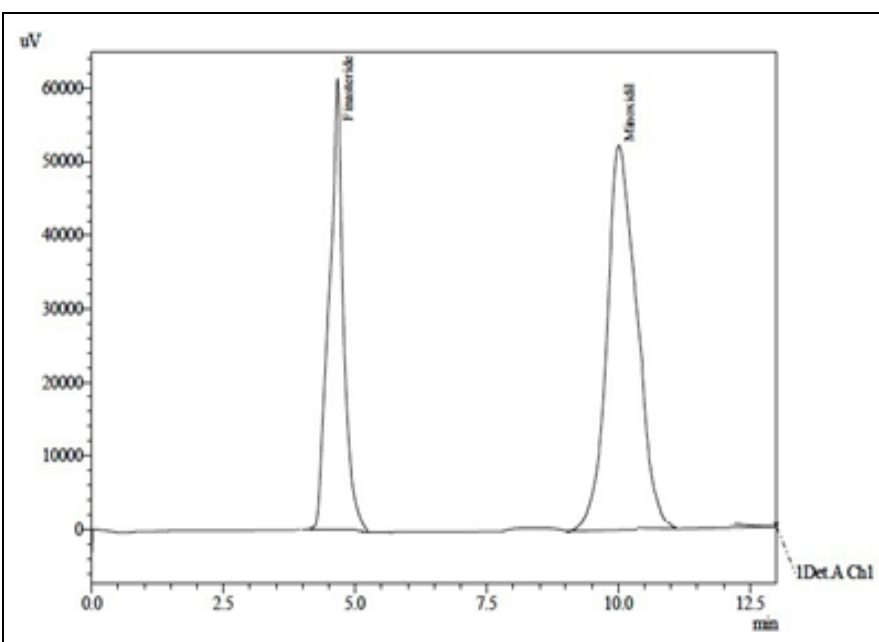

FIG. 1: TYPICAL CHROMATOGRAM OF MINO AND FINA UNDER

\section{Optimized Chromatographic Conditions:} Analysis of marketed formulation:

Sample solution containing of $15 \mu \mathrm{g} / \mathrm{ml}$ of MINO and $0.5 \mu \mathrm{g} / \mathrm{ml}$ of FINA was injected into the chromatographic system and peak area were measured for MINO and FINA. The percentage of label claim of MINO and FINA were calculated and was found to be $99.616 \%$ and $99.04 \%$ respectively.

\section{System suitability test:}

Working standards were injected to the HPLC system in 6 replicates and retention time, theoretical plates, tailing factor, capacity factor and resolution were observed for system suitability of 
proposed method. The results of system suitability test are given in Table 2.

TABLE 2: RESULTS OF SYSTEM SUITABILITY TEST

\begin{tabular}{ccc}
\hline Parameters & \multicolumn{2}{c}{ Data obtained } \\
\cline { 2 - 3 } & MINO & FINA \\
\hline Retention time & $10.005 \mathrm{~min}$ & $4.661 \mathrm{~min}$ \\
Repeatability (n=6) & 3009280 & 1326542 \\
Theoretical plates per column & 7525.465 & 8106.656 \\
Symmetry factor/Tailing factor & 1.077 & 1.019 \\
Resolution & - & 6.262 \\
Capacity factor & & 1.167 \\
\hline
\end{tabular}

\section{Method validation:}

Linearity: Response of detector in terms of peak area to the concentration of analytes in solution was assessed by injecting triplicate injection of solutions containing MINO in concentration range of $12-24 \mu \mathrm{g} / \mathrm{ml}$ and $0.4-0.8 \mu \mathrm{g} / \mathrm{ml}$ for FINA. Peak area vs. concentration graph was plotted and correlation co-efficient values of MINO and FINA were found to be 0.9923 and 0.9939 respectively.

\section{Precision and accuracy:}

The system precision of proposed method was determined by injecting solution having a concentration of $18 \mu \mathrm{g} / \mathrm{ml}$ of MINO and $0.6 \mu \mathrm{g} / \mathrm{ml}$ of FINA for six times and peak area was measured.
The method precision of proposed method was determined by injecting solution having a concentration of 15,18 and $21 \mu \mathrm{g} / \mathrm{ml}$ of MINO and $0.5,0.6$ and $0.7 \mu \mathrm{g} / \mathrm{ml}$ of FINA for three times and $\%$ RSD of peak area was calculated. The accuracy of proposed method was determined by calculating recoveries of MINO and FINA at $80 \%, 100 \%$ and $120 \%$ of test concentration. To the fixed amount of pre-analysed solution $(9 \mu \mathrm{g} / \mathrm{ml}$ of MINO and 0.3 $\mu \mathrm{g} / \mathrm{ml}$ of FINA) an increasing aliquots from working standard solution of MINO and FINA were added. The amounts recovered were calculated. The results of precision and accuracy are given in Table 3 .

TABLE 3: RESULTS OF PRECISION AND ACCURACY

\begin{tabular}{cccc}
\hline Parameters & MINO & FINA \\
\hline & & Precision ( \%RSD) & \\
Repeatability (n=6) & & 0.0361 & 0.1085 \\
Intraday (n=3) & & $0.0114-0.0133$ & $0.0215-0.0275$ \\
Interday (n=3) & $0.0243-0.0329$ & $0.0405-0.0472$ \\
& $80 \%$ & $100.73 \pm 0.2616$ & $100.27 \pm 0.3889$ \\
& $100 \%$ & $100.66 \pm 0.3889$ & $100.83 \pm 1.1737$ \\
& $120 \%$ & $99.95 \pm 0.2757$ & $100.83 \pm 1.1737$ \\
\hline
\end{tabular}

Limit of Detection and Limit of Quantitation:

LOD was found to be $1.589 \mu \mathrm{g} / \mathrm{ml}$ and $0.047 \mu \mathrm{g} / \mathrm{ml}$ of MINO and FINA respectively using the formula:

$$
\mathrm{LOD}=3.3 \times \frac{\sigma}{\mathrm{s}}
$$

LOQ was found to be $4.816 \mu \mathrm{g} / \mathrm{ml}$ and $0.142 \mu \mathrm{g} / \mathrm{ml}$ of MINO and FINA respectively using the formula

\section{Robustness:}

Robustness, a deliberate change in the flow rate and mobile phase composition was made to evaluate the impact on the method. The results reveal that the method is robust enough. The results of robustness are summarized in Table 4.

TABLE 4: ROBUSTNESS STUDY OF MINO AND FINA

\begin{tabular}{|c|c|c|c|c|c|c|}
\hline \multirow[t]{2}{*}{ Sr. No. } & \multirow[t]{2}{*}{ Parameters } & \multirow[t]{2}{*}{ Variation } & \multicolumn{2}{|c|}{ Assay \pm S.D $(n=3)$} & \multicolumn{2}{|c|}{ \% RSD } \\
\hline & & & MINO & FINA & MINO & FINA \\
\hline 1. & $\begin{array}{c}\text { Flow rate } \\
(1 \pm 0.2\end{array}$ & $0.8 \mathrm{ml} / \mathrm{min}$ & $\begin{array}{c}98.87 \\
\pm 0.0507\end{array}$ & $\begin{array}{c}99.23 \\
\pm 0.0453\end{array}$ & 0.0512 & 0.0456 \\
\hline & $\mathrm{ml} / \mathrm{min}$ ) & $1.0 \mathrm{ml} / \mathrm{min}$ & $\begin{array}{c}99.61 \\
\pm 0.3329\end{array}$ & $\begin{array}{c}99.04 \\
\pm 1.4859\end{array}$ & 0.3342 & 1.5003 \\
\hline
\end{tabular}




\begin{tabular}{|c|c|c|c|c|c|c|}
\hline \multirow{6}{*}{2.} & \multirow{6}{*}{$\begin{array}{l}\text { Mobile phase } \\
(70: 30 \pm 2 \mathrm{v} / \mathrm{v})\end{array}$} & \multirow[t]{2}{*}{$1.2 \mathrm{ml} / \mathrm{min}$} & 99.56 & 99.39 & \multirow[t]{2}{*}{0.9607} & \multirow[t]{2}{*}{0.5712} \\
\hline & & & \pm 0.9565 & \pm 0.5678 & & \\
\hline & & \multirow[t]{2}{*}{$68: 32$} & 99.78 & 98.93 & \multirow[t]{2}{*}{1.2485} & \multirow[t]{2}{*}{0.9933} \\
\hline & & & \pm 1.2458 & \pm 0.9827 & & \\
\hline & & 70:30 & $\begin{array}{r}99.61 \\
+03329\end{array}$ & 99.04 & 0.3342 & 1.5003 \\
\hline & & $72: 28$ & $\begin{array}{c}98.67 \\
\pm 0.3897\end{array}$ & $\begin{array}{c}99.16 \\
\pm 0.7829\end{array}$ & 0.3949 & 0.7895 \\
\hline
\end{tabular}

DISCUSSION: A new RP-HPLC method was developed and validated for simultaneous determination of MINO and FINA in combined pharmaceutical dosage form and assured the satisfactory precision and accuracy. The developed method is accurate enough to determine lower concentration of each drug in its pharmaceutical dosage form. The method has been found to be better because of use of a more economical and readily available mobile phase and lack of extraction procedures. The proposed method is more advantageous as compared to the reported method ${ }^{12}$.

Incase of the reported method the chromatograms obtained are wide and have more tailing factor as compared to the proposed method. Further the peak shape and size in the reported method are poor as compared to the method proposed in this paper. Therefore it can be concluded that the proposed method is more reliable and can be used in laboratories with very high accuracy and a wide linear range.

CONCLUSION: The RP-HPLC method proposed in this paper is simple, accurate and precise for simultaneous determination of Minoxidil and Finasteride from its pharmaceutical dosage forms. The excipients in the formulation do not interfere with determination of the two drugs. Thus the method is specific enough to identify the two drugs from their formulation.

ACKNOWLEDGEMENT: The authors are heartily indebted to Shri D. D. Patel, President Om Gayatri Education and Charitable Trust and the
Management of Pioneer Pharmacy Degree College for providing necessary research facilities.

\section{REFERENCES:}

1. Sweetman S: Martindale: The Complete Drug Reference. Pharmaceutical Press, London, UK, Thirty Sixth Edition 2009.

2. Tripathi KD: Essential of Medical Pharmacology. Jaypee Brothers Medical Publishers Pvt Ltd, New Delhi, India, Seventh Edition 2013.

3. Zaheer ZA, Mirza S, Moazzam I and Sayad IW: UV Spectrophotometric determination of minoxidil and its application to the assay in pharmaceutical dosage forms. Der Pharma Chemica 2012; 4(1): 568-573.

4. Ashritha A, Anusha U, Swathi S, Samatha M, Krishna GV and Sreekanth G: A simple RP HPLC method for estimation of Minoxidil in tablet dosage form. Inventi (http://inventi.in/journal/article/rapid/4/10956/pharm-analysisquality-assurance/pi) 2014; 3: 1-4.

5. Gaidhane HK, Bidada JP, Bhusari AS, Navkhare MS, Diwanka GP and Tiwari AH: Development and Validation of Stability Indicating HPLC Method for the estimation of Minoxidil and related substance in topical formulation. Journal of Pharmacy Research 2011; 4(12): 4481-4484.

6. Pfaffen V, Ortiz PI: Electrochemical Determination of Minoxidil in Different Pharmaceutical Formulation. Analytical Sciences 2006; 22(1): 91-94.

7. Ahmadi F, Gholivand MB and Yawari E: Introduce of Minoxidil as a Very Selective ligand for Ultra Trace Detection of Copper Ion by Adsorptive Stripping Voltammetric Method. Analytical and Bioanalytical Electrochemistry 2012; 4(4): 431-446.

8. Lakshmi VN, Koteswara Rao GSN, Rani BR, Manasa K and Bhavani V: Development and Validation of UV Spectrophotometric Method for the Estimation of Finasteride in Tablets. International Journal of Pharma Sciences. 2013; 3(1): 123-125.

9. Basavaiah K and Somashekar BC: Determination of Finasteride in Tablets by High Performance Liquid Chromatography. E-Journal of Chemistry 2007; 4(1): 109-116.

10. Manne S, Kakarla R, Raavi P and Nalluri BN: Rapid analysis of Finasteride in bulk and formulations by RP- HPLC- PDA method. J Chil Chem Soc 2012; 57(4): 1469-1471.

11. Srinivas G, Kumar KK, Reddy YR, Mukkanti K, Kanumula GV and Madhavan P: A Validated stability indicating LC method of assay and related substances for Finasteride. Journal of Chemical and Pharmaceutical Research 2011; 3(6): 987-996.

12. Sudhaker M, Sridhar S and Pravallika C: Analytical Method Development and Validation for Simultaneous Estimation of Finasteride and Minoxidil in Pharmaceutical Dosage form by RP HPLC method. International Journal of Pharma Sciences 2015; 5(2): 954-959.

\section{How to cite this article:}

Patel N and Meshram D: Development and Validation of Analytical Method for Simultaneous Determination of Minoxidil and Finasteride in Pharmaceutical Dosage form by RP-HPLC Method. Int J Pharm Sci Res 2015; 6(11): 4882-85.doi: 10.13040/IJPSR.0975-8232.6(11).4882-85. 